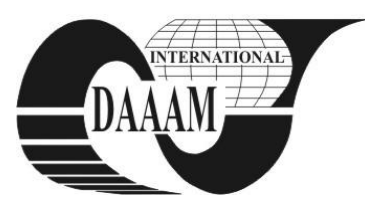

Annals of DAAAM for 2011 \& Proceedings of the 22nd International DAAAM Symposium, Volume 22, No. 1, ISSN 1726-9679 ISBN 978-3-901509-83-4, Editor B. Katalinic, Published by DAAAM International, Vienna, Austria, EU, 2011 Make Harmony between Technology and Nature, and Your Mind will Fly Free as a Bird Annals \& Proceedings of DAAAM International 2011

\title{
USE THE HYDROFORMING BY PRODUCED THE PAD FOR EXTREME CARVING
}

\author{
KROTAK, S[tanislav]; MASEK, B[ohuslav] \& URBANEK, M[iroslav]
}

\begin{abstract}
The aim of this thesis is to show the possible use of hydroforming technology for individual and flexible production. This method uses the pressure of water or hydraulic fluid as a tool to shape products in the rigid form. This technology was used to produce a complexly shaped product which will be ready to place on the market after testing the prototypes. It is a pad for extreme carving. The development of a new concept achieved, for example, better transfer of skier forces to the base, using the great flexibility in the ski bindings and it enables a large bend of the ski when entering into a curve
\end{abstract}

Key word: sheet, hydroforming, pad, carving, FEM

\section{INTRODUCTION}

Effective, fast and repeatable single production, which guarantees the requested quality for every product is the basis of each economic production process (Hosnedl, 2011). In recent times the most popular production processes are those which use nonstandard and unique possibilities of production. One of these possibilities is technology which uses the power of pressurised fluid to form products with a sheet or tube character. The aim of this article is to demonstrate the use of this method during the individual production of a specific product with a small volume to produce a complexly shaped product

\section{HYDROFORMING}

Hydroforming (Siegert, 2001) is a special method of shaping malleable metals using the pressure of water or hydraulic fluid to press the semi-finished product into a form at room temperature. It is the forming of metal plate or tube as cold forming (Erath, 2010) (Fig. 1). Hydroforming is a costeffective way of shaping metals used in the automotive industry in series production for forming complex shapes, for light constructions and more rigid structures. This method has other applications too, for example for forming parts of bicycle frames.

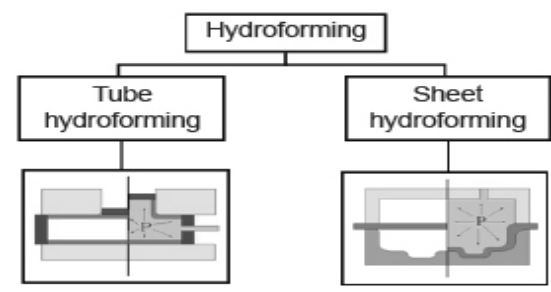

Fig. 1. Illustration of the hydroforming process

\section{CHOICE OF THE PROTOTYPE}

The main aim of this thesis is to show the use of hydroforming for single-part production of an individual product. A pad for extreme carving was chosen as the demonstrator of the individual product. The product is for individual use, without pressure on the price and it is possible to fill gaps in the market. Market analysis was carried out to verify the decision. The result of the market analysis confirmed the decision. The pad has a relatively complex shape and it will be produced by modified hydroforming in the isostatic press. Hydroforming was used in the series production. Use in the single-part production of an individual product is focused on here. Hydroforming was chosen as the production technology because it enables production with only one tool and this is the cavity of the form. It is possible to obtain the final shape of the product with one working cycle by hydroforming. With this type of forming it is necessary to have a rounded product with no sharp edges, and it was important to consider this requirement during the pad design phase. During the design and production process it is necessary take a lot requirements into consideration, therefore Engineering Design Science knowledge was used (Eder\&Hosnedl, 2010).

\section{PROPERTIES OF THE PAD FOR EXTREME CARVING}

There are competitive products on the market, but they are mostly produced in plastic and are liable to failure and breakage caused by outside influence. This pad will be produced from aluminium alloy. It will be more resistant to stress at low temperatures. This product will have rounded edges, which are suitable for production by hydroforming. The rounded edges will give the pad a modern design and the danger of stress peaks will be reduced.

\subsection{Functional of the pad}

The pad is placed between the ski and the binding making the binding higher above the snow, meaning that at extreme skiing angles in a curve, the boots are further from the snow. The contact of shoe and snow is unwanted (Fig. 2), because when the shoe is touching the snow the load on the ski edge is reduced and this leads to the loss of stability and to the skier falling.

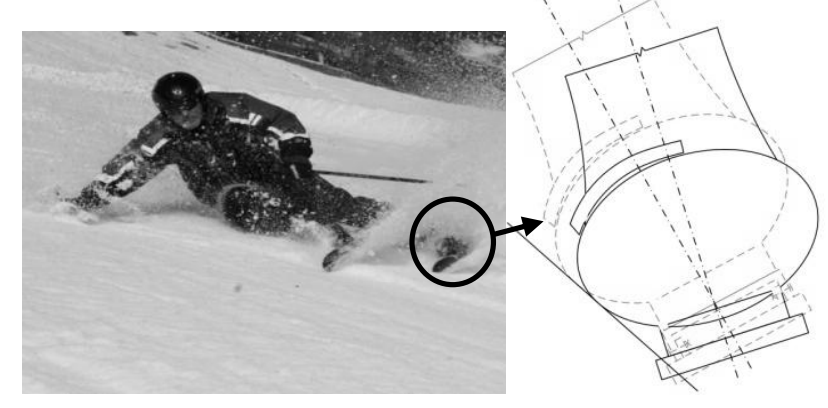

Fig. 2. Illustration of the functional prototype

\subsection{Advantages of the pad}

Advantages of using the pad for extreme carving:

- the skier is higher than the snow, 
- $\quad$ at extreme angles with snow there is no contact with the shoe and the skier does not lose stability,

- $\quad$ it enables a large bend of the ski without changing the stiffness due to the increased pressure in the bindings of the shoe

- $\quad$ it prevents the pulling out of the upper dural skiplate as a result of overloading in screw from combined loads

\subsection{Kinematics of the fixing}

All the advantages listed above are achieved due to the special kinematics of the fixing (Fig. 3).

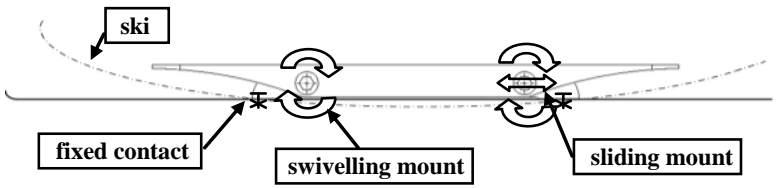

Fig. 3. Functional principle of the carving pad

The pad is fixed to the ski body (Fig. 3) in the front and in the back using fixtures. The front fixture is swivel joined to the ski body and the back fixture is swivel and sliding joined. This fixture means that when the ski bends the rear fixture slides backwards (Fig. 3) and unwanted stresses in the binding do not arise.

\section{DESIGN OF THE PAD}

\subsection{Design proposal for the pad}

A study using CAD software (Fig. 4) was carried out when designing the pad. The study led to some construction and design requirements being clarified. For example, the size of the external radius must be considered not only in terms of design and material but also in terms of manufacturability when using the chosen product technology.

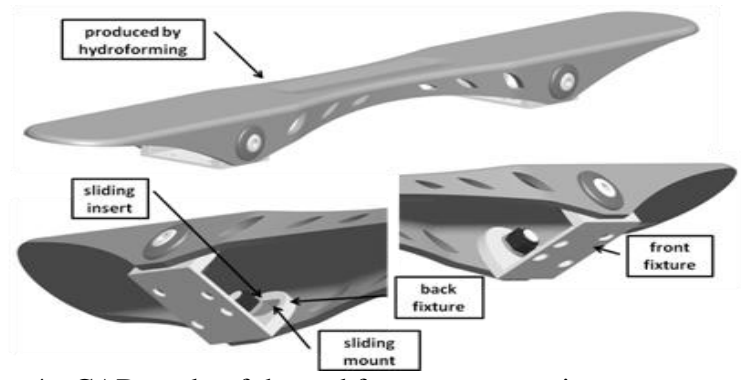

Fig. 4 - CAD study of the pad for extreme carving

\subsection{The form for hydroforming}

Before production the pad for extreme carving it was necessary to design and create a form in which the semifinished product will be formed. The form has to ensure enough quality without further adaptation of the end product. The form has to enable high repeatability. For this example a minimum of eighty pieces of product is requested.

\subsection{Verification of the construction of the form using FEM}

The load of the form and the forming process was analyzed using a numerical simulation. The boundary conditions were the linearly increasing hydraulic pressure on the top surface of the semi-finished product. The material chosen was ČSN 411523 steel. Because it is a symmetrical task it was possible to simplify it to a quarter. The temperature of the forming was $20^{\circ} \mathrm{C}$. During the test forming the sheet filled the form and stress in the material was under the strength limit. Great deformations and stress are in the corners as expected (Fig. 5), which will be optimized in the next step of production. The simple form was designed on the basis of the simulation.

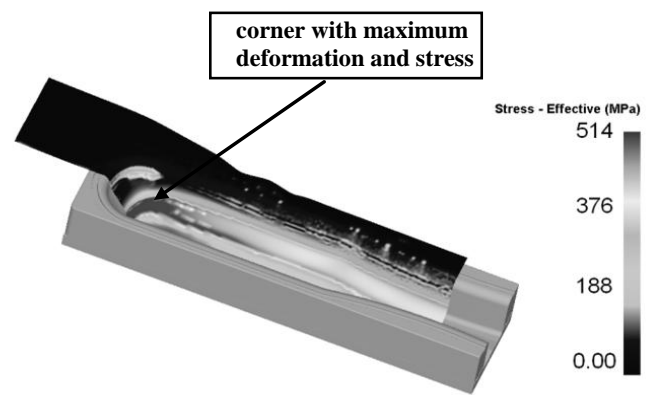

Fig. 5. Stress in the last step of the FEM simulation

\subsection{Technological testing}

Several pieces were produced from sheet metal (Fig. 6), which served to determine the optimum shape of the moulding and to adjust the holder force. The data from the testing will be used to optimize the shape of the semi-finished product and to achieve the required quality in the corners during filling the running radius in contact with the diagonal and longitudinal bending of the product. corners with maximum

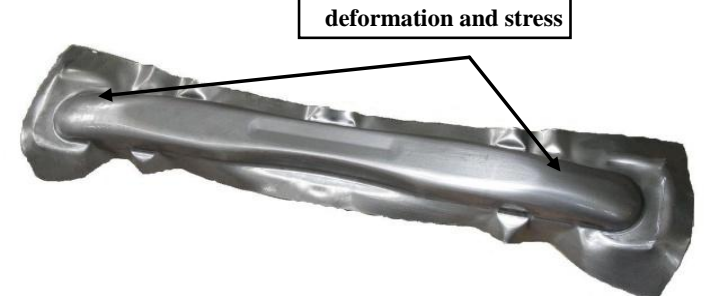

Fig. 6 . The product created by hydroforming

\section{CONCLUSION}

The pad for extreme carving was designed as the demonstrator of the product, which is in agreement with the market requirements and which enables effective production using flexible technology which utilizes the power of pressurised fluid to form products, called hydroforming. Unlike traditional hydroforming, which is used in mass production, forming in a pressure chamber was used for this example and the sheet steel of the semi-finished product was formed by pressurized fluid in a one-piece tool without the need for special apparatus or equipment.

\section{ACKNOWLEDGEMENTS}

This paper includes results created within the projects SGS2011-056 New Unconventional Materials Based on Iron and Vanadium Obtained by Rapid Solidification from Semi-solid State and 1M06032 Research Centre of Forming Technology. The projects are subsidised from specific resources of the state budget for research and development.

\section{REFERENCES}

Eder, w. E.; hosnedl, S.: Introduction to Design Engineering. Systematic Creativity and Management. CRC Press / Balkema, Taylor \& Francis Group, Leiden, The Netherlands, 2010, 456 pp., ISBN: 978-0-415-55557-9

Erath, b., ellsworth, d.: Hydroforming, 2010

Hosnedl, S.: Systémové navrhování technických produktů. Předmět kks/zkm. podklady k přednáškám. plzeň: zču, fst, kks, 2011

Siegert, k.: Hydroumformung von Rohren, Strangpreßprofilen und Blechen. Fellbach: IFU, 2001. ISBN 3-88355-300-X

*** ANSYS Users Manual, Release 12.0 documentation for Ansys 